sólo el romance y la glosa han sido imitados en las demás literaturas europeas. El romance cuenta con extensa bibliografía científica; no así la glosa, cuya valoración ha sido desatendida por las historiadores de nuestra poesía. La peculiaridad española de este tipo de poetización había sido señalada, entre otros, por Lope de Vega y, en el siglo xviII, por Lessing. Aquel artículo, que en sus conclusiones más importantes resume ahora Janner al final de la antología que nos ocupa, necesitaba ser completado con una colección de ejemplos destinados a mostrar las diferentes formas métricas y estructuras ideales de la glosa, a la vez que su evolución desde mediados del siglo xv hasta el año 1700 .

La antología publicada, a pesar de su corta extensión, cumple bien los fines a que su autor la destina, y al mismo tiempo pone al alcance del gran público una bella selección de un género que podríamos calificar de poco conocido como tal, aunque muchas de su manifestaciones sean familiares al lector de nuestros líricos y dramaturgos del siglo de oro. Treinta y ocho son en conjunto las poesías glosadas, que se reúnen por orden cronológico. Las notas que van en las páginas finales nos informan de las ediciones de donde han sido transcritas las poesías, comentan el tipo de glosa que cada una de ellas representa, y nos dan bibliografía que permita ampliar el comentario y los ejemplos. Con este libro ha conseguido el Sr. Janner completar su estudio anterior sobre el mismo tema y realizar además una loable tarea divulgadora.

Madrid.

SAMUEL GILI GAYA

\title{
Henri François Muller, L'époque mérovingienne. Essai de synthèse de philologie et d'histoire. New York, S. F. Vanni, 1945, 304 págs.
}

La publicación de este tomo da cima a más de treinta años de fecundas investigaciones en el campo del latín vulgar. En él Henri François Muller, profesor emérito de la Universidad de Columbia, ha intentado fundir filología e historia para dar un sentido más profundo a los hechos históricos y sociales que podamos coordinar de los textos existentes de la llamada edad oscura de la época merovingia. Aunque las conclusiones del profesor Muller no hayan sido hasta la fecha aceptadas por todos los eruditos ${ }^{1}$, se puede afirmar sin vacilación que, desde Meyer-Lübke, no ha aparecido otra teoría en el campo del latín vulgar que haya suscitado más discusión o haya provocado más investigaciones.

El profesor Muller ve la historia como síntesis y se vale de los hechos linguiísticos para hacerla más comprensible como movimiento social en el tiempo2. Su obra se divide en dieciocho capítulos, de los cuales once son lingüísticos; los otros siete son: 1) El fin del imperio romano y el advenimiento de fuerzas nuevas; 2) Problema social creado por la introducción del cristianismo en Occidente; 3) El cristianismo latino y las invasiones; 4) La creación del pueblo francés: la época de los obispos; 5) ...la época de los monasterios; 6) La expresión cultural de esta nueva sociedad; 7) Síntesis.

La tesis del autor es que la introducción del cristianismo en el Occidente causó una profunda democratización de las masas (págs. 22-23). La propaganda de la nueva religión debió ejercerse entre las masas por gente inculta, y la lengua usada

1 Un excelente análisis de las últimas opiniones sobre la hipótesis de H. F. Muller puede encontrarse en un artículo de A. Burger, Pour une théorie du commun, en Mémorial des études latines, 1947, págs. 162-169. También pueden consultarse H. Pirenne, Mahomet et Charlemagne, Paris, 1947, y G. Bonfante, Los elementos populares en la lengua de Horacio, Madrid, 1937 (Bonfante no está de acuerdo con la cronología del latín vulgar dada por el profesor Muller).

2 En esto sigue a Vossler. Para este concepto de la historia véase Ralph TURner, The Great Cultural Traditions, New York, McGraw-Hill, 1941. 
por estos propagandistas hubo de ser accesible a estas mismas masas. Esto introdujo un cambio en el ideal linguístico aun entre los sectores más cultos de la sociedad (pág. 41). Los padres de la iglesia se pusieron a escribir la lengua que hablaban. Otro efecto de la exaltación espiritual fué un cambio en el acento de intensidad dentro de la frase y en la palabra misma, factor que, combinándose con otros de orden social y político, explica la revolución lingüística románica que puede estudiarse en los textos merovingios. Estos ya no son textos escritos en bajo latín, sino los visibles testimonios de la transformación de la sociedad de entonces. Esta prueba lingüística proporciona el "eslabón perdido" en el proceso de la creación de la mentalidad social y de la civilización europea futura, "cuya grandeza y amplitud superará, y con mucho, a la civilización grecolatina" (pág. 296).

Después de trazar los elementos morfológicos y sintácticos que lentamente se organizaron en la nueva gramática pre-románica - la forma primitiva de la gramática del antiguo francés-, el autor aborda su estudio del vocabulario de la época merovingia. Este capítulo es uno de los más interesantes y menos discutibles del libro. Es de la mejor semántica. Para Muller, como para C. H. Cooley, una palabra "es un vehículo, un barco que flota aguas abajo desde el pasado, cargado con los pensamientos de hombres que nunca hemos visto; y al llegar a comprenderla penetramos no sólo en el espíritu de nuestros contemporáneos sino también en la mente general de la humanidad, continua a través de los siglos"3.

Entre las palabras que trata, citemos algunas de especial interés para los hispanistas: uvas: racemos (pág. 236); tugurium: cavanna (esp. cabaña, pág. 244); toaclum (esp. toalla, pág. 245); curtinis ('cortina', pág. 245); fladone (fr. flan, pág. 246); camisia (encontrada en San Jerónimo, pero que Amalario caracteriza así: "Solent militantes habere lineas quas camisias vocant", pág. 249); "Discalcius, in camisia" (Lex Salica 58, 1e V, pág. 251); cuminitiare (pág. 251); balando (esp. bailar, pág. 253); habeo annos pene cento (pág. 256); precaria (fr. prière, pág. 268); seniores laici (pág. 270).

El libro del profesor Muller será leído con interés por todos los estudiosos de filología románica. Y aun los que no acepten sus tesis se sentirán incitados a hacer otras investigaciones sobre los orígenes de las lenguas románicas: un campo fascinante.

College of the City of New York.

LOUIS FURMAN SAS

Pedro Henríguez Ureña, Historia de la cultura en la América hispánica. Colección Tierra Firme, núm. 28, Fondo de Cultura Económica, México, 1947, 240 págs., ilustr.

Esta Historia de la cultura en la América hispánica -que su autor, con el afán de rigor que le distinguió, insistía en llamar "breve"- es la primera obra comprensiva y justa sobre tan capital aspecto del desarrollo de nuestros pueblos. Porque aunque puedan señalarse otros trabajos semejantes - véanse por ejemplo los mencionados en primer lugar en la Bibliografía de esta obra-, ninguno puede en rigor considerarse "historia cultural", sino aportaciones parciales, muchas de ellas excelentes, para esa empresa mayor que tocaría consumar, aunque sumariamente, al maestro dominicano.

Las limitaciones de la extensión a que debió reducirse esta Historia y la amplitud y anarquía de los materiales que era preciso tamizar y organizar presentaban a cada paso problemas de método, de documentación, de estilo y de síntesis que

3 Cita de C. H. Cooley, Social organization, a study of the larger mind, 1909, pág. 69. 